Acta Universitatis Nicolai Copernici • Pedagogika XXXVII/1/2019

Nauki Humanistyczno-Społeczne • Zeszyt 447

DOI: http://dx.doi.org/10.12775/AUNC_PED.2019.010

\author{
Angelika Lenart \\ Faculty of Social Sciences \\ Catholic University of John Paul II in Lublin \\ https://orcid.org/0000-0002-4106-1518
}

\title{
Children AfTer TRAumatic EXPERIEnCES
}

\begin{abstract}
:
Children who have experienced traumatic events in their lives and grew up in an environment that neglected their needs and in which abuse occurred will invariably feel the long-term and varied impact of these events on their lives. Consequently, working with children who have experienced trauma is vitally important but also difficult. Caregivers and educators should first learn about their history and understand the impact of the traumatic events they have experienced before focusing on their behaviour. They ought to build appropriate relationships that will allow the children to gain confidence and a sense of security. This article presents the phenomenon of trauma and its types, the impact of traumatic experiences on child development and the consequences that follow, demonstrating what work with a child should look like after traumatic experiences.
\end{abstract}

Ke yw ord s: trauma, trauma experience, PTSD, ASD, posttraumatic development, relationship disorders.

\section{STRESZCZENIE:}

Dzieci, które doświadczyły w swoim życiu traumatycznych zdarzeń, wzrastały w środowisku, które zaniedbywało potrzeby i w którym dochodziło do nad- 
użyć, będą odczuwać długotrwały i różnorodny wpływ tych zdarzeń na życie. Dlatego tak ważna i trudna jest praca z dziećmi, które doświadczyły traumy. Opiekunowie i wychowawcy zanim skupią się na zachowaniu dziecka powinni najpierw poznać jego historię, zrozumieć wpływ zdarzeń traumatycznych, których doświadczyło. Zbudować odpowiednie relacje, które pozwolą na zdobycie zaufania i poczucie bezpieczeństwa. $\mathrm{W}$ artykule przedstawione zostało zjawisko traumy i jej rodzaje, a także wpływ doświadczeń traumatycznych na rozwój dziecka i konsekwencje za tym idące. Ukazano, jak powinna wyglądać praca z dzieckiem po przeżyciach traumatycznych.

Sło w a klu c z e : trauma, doświadczenie traumy, PTSD, ASD, rozwój potraumatyczny, zaburzenia więzi.

\section{Introduction}

7 he aim of the article is to present the phenomenon of trauma in I children and adolescents, its consequences as well as help with regards to and prevention of post-traumatic events. Any abuse of a child affects all areas of their development. The consequence of this may be disorders of physical health, mental development, mental condition, and the ability to live with other people. Situations and phenomena that cause stress can become the root of traumatic experiences and affect children and young people to varying degrees, becoming the reason for their disorders.

Negative emotions such as fear, anxiety and suffering take away the child's sense of security and trust in adults. Gradually developing destruction can lead to irrational, antisocial behaviour, mental disorders, diseases and suicidal behaviour. Being a victim or a witness of events threatening the health or life of close relations is strictly associated with traumatic experiences. Such events are accompanied by a sense of helplessness, powerlessness, loneliness, anxiety and being overwhelmed. Subsequently, tension and psychomotor agitation in children can be noticed as well as changes in everyday functioning.

The consequences of trauma affecting all aspects of a person - the psyche, mind and body - are always left behind or carried into later life. A human body in which there are signs of a past, or constantly ex- 
perienced suffering, needs support, help from loved ones and sometimes even assistance from third parties. The child's psyche in particular requires a subtle conversation in which some difficult topics will be addressed.

\section{Trauma - diagnosis}

We talk about trauma when a child experiences or is a witness to situations that threaten the life and health of them or their loved ones. Such situations are overwhelming for a child and often arouse negative emotions. They can be a source of extreme stress, dismay and helplessness; they affect the behaviour of a child who may become confused, unpredictable, and often overly agitated.

Trauma is most often defined as an experience whereby a person is confronted with fear or helplessness. The key elements are the emotions felt by the individual at a given moment and they determine whether the event will be a traumatic experience or not ${ }^{1}$.

For P. Sztompka, trauma is a 'specific type of pathology of social subjectivity (i.e. what is understood in the theory of social becoming as a comprehensive, systematic property of the human community that enables creative self-transformation). This pathological condition occurs in specific structural and cultural conditions («favourable context»), under the influence of specific previous social changes («traumatogenic events»), interpreted in the light of existing cultural resources as traumatic'2.

The earliest traumatic experiences can be experienced in the prenatal period. Any negative, intense and significant experience affecting the safety of the mother will affect the unborn child, and it can be said that it 'moves to it'. There are also direct factors directly threatening foetal life, e.g. alcohol, nicotine or drug poisoning. Trauma in children can also be associated with tough delivery and associated compli-

1 A. Popiel, E. Pragłowska, Psychopatologia reakcji na traumatyczne wydarzenia. In: Konsekwencje psychiczne traumy - uwarunkowania i terapia, eds. J. Strelau, B. Zawadzki, M. Kaczmarek, Warsaw 2009, p. 38.

2 P. Sztompka, Trauma wielkiej zmiany, Warsaw 2000, p. 20. 
cations; a longer separation from the mother, difficulties in feeding the baby, and certain medical procedures immediately after the birth can result in traumatic sensations ${ }^{3}$.

Depending on the stage of child development an event may be assessed differently, and the event may be accompanied by different emotions and ways of dealing with one's own reactions and ability to accept. When such experiences engulf or even overwhelm a child, a sense of anxiety and helplessness, excessive vigilance, indignation and often fear might become entrenched. Such experiences may be accompanied by a sudden increase in pulse, body tremor, dizziness, vomiting, or loss of sphincter control. Long-term post-traumatic stress disorder (PTSD) in children can manifest as difficulty in concentrating, falling asleep, nightmares, eating problems, mood and behaviour changes, arousal, and even depression in extreme situations. The result of these behaviours can be inadequate reactions in everyday situations, difficulty in establishing relationships with peers, as well as a failure to properly integrate with the environment. Put simply, a traumatic experience in childhood increases the risk of multiple problems later in life.

The employees of the SOS Children's Villages in Poland distinguish the following types of trauma. Acute trauma is a time-limited, single traumatic event intensively experienced by a child. It is a sudden and violent disruption of their sense of security, i.e. a road accident, dog bite, rape, or act of terror. Another term is chronic trauma, i.e. situations in which a child experiences many consecutive traumatic events where the effects accumulate and each subsequent event reminds the child of the previous one and strengthens its destructive impact. It destroys mental balance and self-esteem. A young person can be both a victim of physical violence, mental abuse, sexual violence, or neglect, as well as a witness to stressful events in their environment. We can therefore say that they are victims of complex trauma. This term is used for the exposure of chronic trauma, when the persons responsible

3 B. Skotnicka, Prenatalne, perinatalne i postnatalne czynniki zagrożenia niepełnosprawnościa intelektualną: profilaktyka i edukacja, „Problemy Edukacji, Rehabilitacji i Socjalizacji Osób Niepełnosprawnych", no. 1 (2014), p. 70. 
for neglect and harm done to the child are primarily parents and caretakers who have most likely suffered their own trauma in childhood ${ }^{4}$.

Negligence is the failure to guarantee and meet the basic needs of a child, either by a parent or a caretaker. It can be a conscious or unconscious action, indicating incompetence and lack of interest. This is the most common form of abuse and the effects have far-reaching consequences for child development. The ambivalence of the phenomenon of neglecting indicates a form of complex trauma.

PTSD is recognised as a disease entity that leads to a disorder caused by external factors without the need for internal factors. In 1980 the term PTSD was introduced into DSM-III, which later evaluated it. It defined a stressor as an event that could cause a distress reaction in everyone. In subsequent DSM editions, the type of event was specified more precisely ${ }^{5}$.

Currently the DSM-5 Classification published in 2013 is in force. The changes to the diagnostic criteria from DSM-IV to DSM-5 include, among others, the relocation of PTSD from the anxiety disorders category to a new diagnostic category entitled "Trauma and Stressor-related Disorders". It introduces separate PTSD diagnostic criteria for adults, adolescents and children over six, as well as separate diagnostic criteria for children under six years of age ${ }^{7}$.

According to research carried out in Poland, it appears that up to the age of maturity every fourth child has had traumatic experiences; as many as $41 \%$ of children aged 11 to 17 have experienced violence from close relatives $^{8}$. Many factors affect the risk of PTSD in children. The

4 B. Kulig, T. Saj, Szkoła wrażliwa na traumę, Warsaw 2019, pp. 6-7.

5 B. Dudek, Zaburzenie po stresie traumatycznym, Gdańsk 2003, pp. 14-15.

6 Posttraumatic Stress Disorder in the DSM-5: Controversy, change, and conceptual considerations, https://www.ncbi.nlm.nih.gov/pmc/articles/PMC5371751/ (access 09.09.2019).

7 W. Gruszczyński, Trauma a zespół stresu pourazowego. In: W przestrzeni stresu i lęku medyczne i społeczne aspekty traumy, red. J. Jośko-Ochojska, Katowice 2016, p. 159.

8 J. Włodarczyk, K. Makaruk, P. Michalski, M. Sajkowska, Ogólnopolska diagnoza skali i uwarunkowań krzywdzenia dzieci, https://diagnozakrzywdzenia.pl/ raport.pdf (12.10.2019). 
factors determining the formation of PTSD in children and adolescents can be divided into the following categories:

- pre-traumatic - these are experienced traumas and existing mental disorders that play a significant role in the victim and their family members. They also emphasise factors such as neuroticism, harm avoidance and emotional reactivity;

- peritraumatic - this is awareness of the threat to one's own life and that of others, negative emotions, injuries that accompany trauma, as well as dissociative symptoms;

- post-traumatic - this refers to the role of social variables, i.e. social support from family and the community. They are secondary stressors that are conditioned by the aftermath of a traumatic event ${ }^{9}$.

In the DSM-IV classification, the decision was made to introduce a new disease entity called Acute Stress Disorder - ASD. The ASD diagnosis structure reproduces the PTSD diagnosis structure as it uses the wording in terms of stressor definition, re-experiencing, arousal, avoidance, duration and rejection criteria. However, there are significant differences between the two entities. An additional criterion unique to ASD is the group of dissociative symptoms, and to meet this criterion an individual must have at least three of the following dissociative symptoms:

a) a subjective feeling of emotional numbness or alienation;

b) a reduced awareness of the environment;

c) derealisation;

d) depersonalisation;

e) dissociative amnesia ${ }^{10}$.

These symptoms should or may occur during an injury or within a month after the injury. When diagnosing ASD, it is also necessary to re-experience the injury in at least one of the following ways: recurring

9 M. Gustak, M. Głuszek-Osuch, Czynniki warunkujace PTSD u dzieci i młodzieży. In: Konsekwencje psychiczne traumy - uwarunkowania i terapia, eds. J. Strelau, B. Zawadzki, M. Kaczmarek, Warsaw 2009, p. 155.

10 R.A. Bryant, A.G. Harvey, Zespół ostrego stresu. Teoria, pomiar, terapia, Warsaw 2003, p. 13. 
images, thoughts, dreams, delusions, episodes of "paroxysmal hypermnesia" or "retrospective flash", or a feeling of reliving the experience, suffering in contact with stimuli reminiscent of a traumatic event. It is also important that the trauma is followed by clear signs of anxiety or arousal. The condition for the diagnosis of ASD is the interruption of social and professional functioning, which must last for at least two days after the injury but not longer than a month ${ }^{11}$.

One of the most important criteria distinguishing between ASD and PTSD is the duration of symptoms after a traumatic event. For ASD, they can occur from the moment of the event up to four weeks; in contrast, in PTSD they last for months, and with chronic PTSD, even years after the trauma.

According to the DSM-5 Classification, PTSD and ASD are no longer included in the anxiety disorder category. They are recorded in the category of disorders related to trauma and stress.

Tedeschi and Calhoun introduced the concept of post-traumatic growth, which was described as a phenomenon related to the experiencing of a traumatic event meaning an improvement in functioning compared to the period before the trauma. They described a set of positive changes which resulted from surviving a traumatic experience among people who then attempted to cope with the new situation. This concept means regaining balance, undergoing transformation and reestablishing the level of functioning in place before the traumatic event occurred. It is said that post-traumatic growth can be determined by four elements:

- growth takes place in a situation of severe crisis, not in mild stress;

- it accompanies individual events, which are important life changes, but not the result of errors in perception or interpretation of events;

- rather than the way itself, growth is experienced in the category of the result of a particular proceeding;

11 Ibidem, pp. 13-14. 
- relative and radical change in the functioning of the individual ${ }^{12}$.

Posttraumatic growth is a cognitive process in which those experiencing trauma find positive interpretations and meaning in traumatic events. The result of this process is a positive change in interpersonal relationships and in everyday life. People experiencing trauma find positive values, a sense of victory and they gain an increased ability to cope with life and stressful situations. They are capable of establishing new goals and challenges. Post-traumatic growth is similarly defined in children and adolescents. However, children are less resistant and they lack life experience as well as integrated personality; thus, positive changes in post-traumatic growth are more difficult to achieve.

\section{Trauma and child development}

Traumatic experiences have long-term consequences in the child's life and therefore affect its quality. They disrupt the functioning of the nervous system, which results in developmental disorders in the emotional, physical, cognitive, social and health spheres. Pervasive anxiety ruins many areas of life, hinders interpersonal relationships and limits many processes relevant to the acquisition of knowledge.

Negative experiences, traumatic events and injuries in a small child have an impact on various biological processes and phenomena. For example, they can affect the development of the prefrontal cortex, increase the secretion of adrenaline and cortisol. The loss of glial cells stabilising the level of glutamine, which is a neurotransmitter that activates the work of nerve cells, is another potential consequence. In a normal state glutamine stabilises the work of the amygdala, but in stressful situations glutamine levels within the amygdala decrease and this area becomes over-activated. The amygdala is activated in emergency situations, it supports the whole body and cannot be modified. Any information that could reduce the level of negative emotions and the body's response to stress cannot be received by the amygdala.

12 P. Kwarta, J. Grzelińska, T. Pietras, Potraumatyczny rozwój u dzieci i młodzieży - perspektywy badawcze, „Postępy Psychiatrii i Neurologii”, vol. 21, no. 3, Łódź 2012, p. 4. 
A traumatic event also reduces the level of BDNF (brain-derived neurotrophic factor), which is responsible for strengthening the connection in the hippocampus and stimulates the growth of neurons responding to serotonin. This phenomenon causes a decrease in cell growth in the hippocampus areas responsible for nerve cell renewal in adult life, meaning the nervous system loses the ability to adaptive responses in stressful situations and the stress response system (HPA axis) is constantly over-activated. The HPA axis includes the hypothalamus, pituitary gland and adrenal cortex. The autonomic nervous system together with the HPA axis are activated under stress because they are responsible for reactions in extreme situations. When the hypothalamus is stimulated, adrenocorticotropic hormone (ACTH) is released in the pituitary gland. Moreover, when ACTH reaches the adrenal cortex, glucocorticoids (including cortisol) are released, which inhibits both tropic hormone and ACTH. The HPA axis reacts more slowly than the autonomic nervous system but still plays a key role in long-term stress. Increased glucocorticoid concentration excessively increases synaptic conductivity and the supply of calcium ions to the hippocampus cells, which in turn leads to their death ${ }^{13}$.

The human brain consists of billions of neurons and glial cells. During its infancy, the brain develops from bottom to top, from basic to more complex structures. The most primitive structures are formed first. Lower parts of the brain (brainstem, cerebellum, medulla oblongata) are responsible for basic life functions, i.e. breathing, heart rate, temperature, metabolism and integration of auditory and sensory stimuli. The so-called "reptilian brain" is the structure emerging in the first instance. This is followed by the "emotional brain", or the "mammalian brain" limbic system, as it is characteristic of mammals. It is responsible for reacting, emotional reactions, reproducing information, learning, and long-term memory. The final development stage is the "thinking brain", which creates the cerebral cortex with frontal lobes that are unique to humans. The highest cortical areas are responsible for complex processes, i.e. logical and abstract thinking, decision making,

13 T. Jadczak-Szumiło, G. Wrona, Dziecko pod opieka grupy roboczej. Diagnoza i opracowanie planu pomocy. Poradnik Praktyczny, Kraków 2018, pp. 35-37. 
behaviour control, and predicting the consequences of the procedure. This area is primarily developed after birth ${ }^{14}$.

The human brain is undoubtedly a phenomenal organ. When developing, it creates neural connections that are important for the relationship between children and their caretakers. When parents devote a lot of attention and time to a child and meet their needs, the nerve connections in their brain develop much more effectively and they are stronger and more numerous. However, children with traumatic experiences suffering from a deficiency of positive interpersonal relationships - i.e. their basic needs are not met - suffer from a limited number and quality of neural connections. Stress-related high and long-lasting levels of cortisol and adrenaline affect the structure and development of the brain and therefore lead to changes in both the structure and functioning of the brain. Trauma can play a significant role in reducing the size of the cerebral cortex and cause disturbances in the communication of the cerebral hemispheres, potentially affecting memory, attention, awareness, thinking and language perceptions. An important fact is that the trauma experienced by a child causes the brain to develop in such a way as to adapt to the situation. As a result, we discuss a significant activation of the "emotional brain"15.

The age of the child has a significant impact on the psychological and behavioural consequences of trauma. In the early stages of a young child's life, traumatic experience affects the structure and functioning of the brain and thus the development of intelligence and emotions, increasing anxiety and a sense of security; this becomes evident in the later stages of their development and life.

The symptoms of trauma experience in young children may be intensified suffering reactions expressed by physiological and sensory reactions. They become timid, passive, and quiet, show regressive behaviour and anxiety reactions, and have a poor understanding of causes and effects. Even before children develop speech skills they retain the emotional memory of their trauma, but they do not have conscious memories of these events. As the child's language skills develop, the

14 B. Kulig, T. Saj, Szkoła wrażliwa na traumę, Warsaw 2019, pp. 18-19.

15 Ibidem, pp. 18-20. 
first conscious memories appear, which is why any trauma that takes place during this period can be remembered fragmentarily ${ }^{16}$.

Children of school age with trauma experience suffer from disorders of the brain areas responsible for managing anxiety, fear and aggression. They have problems with attention span, controlling impulses and controlling physical reactions in the face of danger. As a consequence, these individuals are likely to experience disturbances of concentration, sleep, learning difficulties, and are unable to control the reaction to stimuli that cause anxiety. They present excessively submissive behaviour, experience unwanted intrusive thoughts, reconstruct traumatic events, plan how they could be prevented, change their behaviour from shy and withdrawn to aggressive, think about revenge, and do not trust adults yet simultaneously expect safety and protection from them ${ }^{17}$.

Teenagers struggling with trauma may have problems with the development of the prefrontal cortex, which is responsible for the consequences of behaviour, realistic assessment of the situation, anticipation, planning, and achievement of goals. Changing the level of dopamine during puberty leads to increased risk taking; therefore, teens who have experienced trauma are at greater risk of recklessness, destructive behaviour, and poor academic performance. They are also exposed to the risk of making so-called "bad choices", aggression and ultimately hooliganism, robbery, self-mutilation, lack of trust and revictimisation; in particular, when they experience chronic or complex trauma, they are vulnerable to abusing psychoactive substances. They are also prone to low self-esteem and depression ${ }^{18}$.

\section{Attachment disorder}

The way a parent meets the child's basic psychological needs, i.e. safety, acceptance, belongingness, and providing love and attention, determines the development of the child's relationship with the parent. Most

\footnotetext{
16 L. Spear, The behavioral neuroscience of adolescence, New York 2010, p. 20.

17 Ibidem, pp. 20-21.

18 Ibidem, pp. 21-23.
} 
often, the attachment reaction occurs between the child and mother. The primary carer attachment theory is called the "attachment figure". It is worth noting, however, that it does not matter whether the person who provides care for the child is a biological parent, or female or male. For a bond to be formed, the quality of interaction is important. Through play, we participate and relate to the thoughts and feelings of the child's thoughts and feelings which it translates into trust, a sense of security and attachment ${ }^{19}$.

Attachment is a pattern of behaviour presented in a child-carer relationship as the child knows how to draw the carer's attention to their needs. Attachment can be categorised into the following patterns:

- secure attachment - a lasting relationship with the carer in which the child is certain that the object of attachment is available in every situation and reacts sensitively. Children and adults find happiness and satisfaction in this bond. Their relationships complement each other, and the mother's behaviour is an adequate response to the child's needs. As a result, the child is mentally resistant, independent, can control their feelings and is interested in contact with the mother, but also trusts strangers;

- anxious-avoidant attachment - characterised by a child's lack of trust in the mother. This pattern develops when the carer is rejecting, over-controlling and obtrusive. By fearing and anticipating injury, the child avoids contact with the mother and manifests defensive behaviour. The child is friendly towards strangers, reacts with indifference to separation and becomes overly selfreliant and independent. Such individuals tendentially inhibit unpleasant emotions and demonstrate positive ones to avoid rejection. These situations lead to emotional development disorders. The lack of physical and mental accessibility of the attachment object is the result of such a pattern in a child;

- anxious-ambivalent attachment - due to the child's uncertainty that the mother is available to them. The carer is inconsistent and insensitive to their needs. The child has uncertainty and

19 Ch. Taylor, Zaburzenia przywiązania u dzieci i młodzieży. Poradnik dla terapeutów, opiekunów i pedagogów, Sopot 2017, pp. 30-37. 
strong anxiety associated with separation from the mother. They are afraid of being abandoned emotionally, unable to freely explore the environment, show a tendency towards anxious attachment to their mother, and resist contact and interaction with other people. As a consequence, the children do not develop social competences. In the relationship, they will present an ambivalent attitude towards the attachment object that leads to inadequate behaviour and disturbs the child's emotional development. In this pattern, the mother's attitude is characterised by a lack of coherence and stability, while the child thinks of themselves as a person who does not arouse love and is ineffective;

- disorganised attachment - children present a lack of a fixed or coherent attachment pattern. They are unable to develop strategies to draw the carer's attention to their needs as the carer uses many different methods and strategies of education in an unpredictable way. This is often associated with addiction, domestic violence, mental illness on the part of the carer, child abuse or neglect. As a consequence, the person who should ensure security becomes a source of uncertainty, fear and anxiety. The child shows little coping ability and makes characteristic attempts to attract attention by using strategies typical of the anxious-avoidant or anxious-ambivalent groups. The desire for intimacy is intertwined with anxiety, hatred and aggression. Unable to predict the threat, the child is constantly in suspense and readiness and thus experiencing anxiety; helpless and fearful, they live in a state of strong agitation and distorted emotions. Children from this attachment group can be difficult to educate or even psychopathological ${ }^{20}$.

In the classification of mental disorders - the DSM-5 - the diagnosis of this problem is based on a set of behaviours which are mainly social in nature. This classification describes bond disorders in infancy and early childhood (beginning before the age of five). There are clearly

20 A. Słaboń-Duda, Wczesna relacja matka - dziecko i jej wptyw na dalszy rozwój emocjonalny dziecka. "Psychoterapia", vol. 2, no. 157 (2011), pp. 11-18. 
disturbed and developmentally maladjusted ways of establishing social bonds and these manifest themselves in two forms:

- inhibited - that is, the persistent inability to properly initiate or respond to most social interactions. This is characterised by excessive vigilance, high ambivalence, inhibition and conflicting relationships. Such a child does not strive for initiative in interpersonal relations and reacts improperly for their age;

- unrestrained - characterised by "diffuse" bonds manifested by undifferentiated sociability with a clear inability to show adapted, selective bonds. The child manifests excessive confidentiality even in relations with unknown people as a result of behavioural or emotional disorders ${ }^{21}$.

\section{Helping children cope with trauma}

Working with children after traumatic experiences is a specific skill. The most important element of working with them is establishing and maintaining emotional contact, which gives the child a sense of security, acceptance and understanding. Only in the later stage does therapy, rehabilitation, education and discipline take place ${ }^{22}$.

A good field for observation and assessment of the child's functioning is school, in particular teachers and all the non-teaching staff. They see the child every day and it is easier for them to observe their physical health as well as social and emotional functioning. The school, apart from education, activates, provides stimulation and socialisation. Everyday life at school means peer relations or cooperation in a group, but also grades and tests, which generates increased stress and can overwhelm children with trauma.

Schools should implement an appropriate support system for children after traumatic experiences:

21 A. Sczepaniak, Zaburzenia więzi jako efekt wczesnodziecięcego krzywdzenia dziecka. "Dziecko krzywdzone. Teoria, badania, praktyka", vol. 15, no. 3 (2016), pp. 74-90.

${ }^{22}$ L. Drozdowski, System opieki nad dzieckiem i rodziną, Warsaw 2009, p. 91. 
- It is vital to ensure the physical and psychological security of the entire school community.

- Activities should be focused on the individual case of a given student, including areas such as:

- family situation;

- contact with peers;

- self-esteem;

- development of knowledge acquisition skills;

- social marginalisation;

- consideration of culture, tradition and religion.

- The knowledge of educators and school staff regarding the impact of traumatic experiences on students should be broadened, including:

- the ability to recognise behaviours and reactions that may be the result of traumatic stress;

- intervention in behaviour resulting from traumatic stress, seeking solutions, openness, sensitivity, sharing knowledge and insights, a sense of security.

- Close cooperation among carers, parents and teachers, sharing knowledge, experiences and comments in supporting students with trauma experience.

- Creation and the possibility of students' participation in preventive programmes developing intrapersonal and interpersonal competences, for instance psychoeducation, sport and recreation, arts, in particular, music, dance and theatre activities which help in releasing negative emotions and create the possibility of self-realisation.

- A crisis management and response scheme should be developed for when a student manifests aggressive behaviour.

- Existing knowledge about trauma and post-traumatic stress should be supplemented and updated. Appropriate changes in the making of school regulations and procedures should also be analysed and introduced.

- Cooperation with other institutions, government and non-governmental organisations. 
- Prevention and support of teachers experiencing secondary traumatic stress.

Children from properly functioning families approach the learning process with interest and curiosity. They can find themselves in peer relationships which are not always unambiguous but often generate conflicts and even fights. For children who have had traumatic experiences, the same events can cause terror, fear, anxiety, and even preclude learning. This is because life has taught them that one should be constantly alert in case of sudden unforeseen and even dangerous situations such as those they have witnessed at home, and yet the school abounds in situations which are characterised with uncertainty, chaos and stress.

The carer, teacher, and educator ought to have relevant knowledge about the phenomenon of trauma itself and its impact on children. They must reckon with and be prepared for difficulties and complications related to care and upbringing. Children who have had traumatic experiences often face social maladjustment, adaptation difficulties and personality disorders. Caregivers should therefore focus on the child's behaviour and be aware of their therapeutic decisions in order to react appropriately to the causes and respond to the needs and motives that the child is guided by during their interactions.

'Dysfunctional and threatening behaviour must meet with an adequate response, but at the same time the child's needs should be met and the child cannot be punished for manifesting trauma symptoms' ${ }^{23}$. A lack of understanding regarding dissociative disorders and developmental trauma by caregivers, educators and teachers is a serious problem because the goal is caring for the best interests of the child.

Children with developmental trauma have difficulties in focusing and remembering; they get the impression as if they were absent. An important element, apart from the joint operation of the family and the school, is establishing student-teacher relationships. All long-term relationships with adults give the child a sense of security, stability, predictability and wellbeing. The educational impact then focuses on

23 B. Kulig, T. Saj, Szkoła wrażliwa na traumę, Warszawa 2019, p. 35. 
the students' resources, their talents, strengths and interests, therefore providing them with self-esteem.

Emotional and social development is important in children with dissociative disorders because their adaptability is limited. They have difficulty functioning in the school environment, and the school system is not capable of providing adequate care that would be adapted to their level of development. An optimal solution for children with developmental trauma would be an individual course of teaching with trustworthy teachers who are able to show love and a sense of security, as well as contact with properly selected peers. This approach would have a positive effect on abandoned and neglected children who lack bonds and trust as well as adequate relationships with others.

In the context of school, a child's trauma will affect other students, teachers and the entire school community. The main purpose of school is to focus on the teaching process, supporting students in their intellectual and cognitive development. School staff strive to provide students with safety as well as good mental condition. Accordingly, raising the knowledge and skills of teachers and other staff helps understand the behaviour of students with traumatic experiences.

In addition, some therapies for working with people who have experienced trauma are recommended by The National Child Traumatic Stress Network in the US:

- Eye Movement Desensitisation and Reprocessing (EMDR) - desensitisation therapy using eye movement;

- Child-Parent Psychotherapy (CPP) - a dyadic, relationship-based treatment for parents and young children;

- Prolonged Exposure Therapy for Adolescents (PE-A) - this consists of exposing the patient to things that make them nervous, as well as memories of the traumatic event.

Therapeutic approaches and forms of support will also be helpful, i.e.

- Dyadic Developmental Psychotherapy (DDP);

- Theraplay;

- the narrative approach in trauma therapy;

- Aggression Replacement Training (ART); 
- training in professional response to an attack (PART) ${ }^{24}$.

\section{Conclusion}

Traumatic events experienced by children are not only a family problem, but also a school problem. The mutual relationship between these institutions and their subjects is crucial for the prevention of this phenomenon. Child welfare is the supreme value that should be nurtured. This is the responsibility not only of parents and carers but also teachers, educators and therapists.

In addition to physical health disorders, the consequences of trauma also include emotional and cognitive disorders; their severity will be associated with individuality of character, personality, and also with the frequency or degree of participation in a traumatic event. Therapeutic work should aim at recognising the significance of the trauma experienced in the child's current life and enable it to be balanced.

The main task of teachers and therapists in consultation with parents in the fight against trauma is to offset its effects and restore the child's wellbeing. Through good contact and building positive relationships among the child, therapist and educator, it is possible to transform the experiences of loneliness and suffering, and reduce their meaning. Subsequently, the ability to recognise their needs and emotions can be developed and the acceptance of various emotional states can be introduced.

Time heals all wounds when we use it wisely. Although no one is able to take away a child's pain, fear and sense of loss, each of us, even a non-specialist, can help a child to once again live a full life as they did before when they had the curiosity and optimism to be receptive to new experiences and love. Each of us can help a child and teach them how to reduce negative emotions in their lives. That is why the topic of children affected by traumatic experiences and the help they receive in fighting this experience is so important and necessary.

${ }^{24}$ Ibidem, p. 50. 


\section{References}

Bartnikowska, U. „Z doświadczeniami „przetrwania” - w szkole. O adaptacji szkolnej socjującej dziecka”. In: „Dysocjacja - terra incognito? - od adaptacji do patologii. Zaburzenia dysocjacyjne u dzieci po traumach", eds. L. Drozdowski, J. Helios, W. Jedlecka, G. Lewko, H. Dufner, U. Bartnikowska, Annals of Diagnostic Paediatric Pathology 3-4 (2013): 103-130.

Bryant, Richard A. Harvey, Allison G. Zespót ostrego stresu. Teoria, pomiar, terapia, Warsaw: Wydawnictwo Naukowe PWN, 2003.

Dudek, B. Zaburzenie po stresie traumatycznym, Gdańsk: Gdańskie Wydawnictwo Psychologiczne, 2003.

Drozdowski, L. System opieki nad dzieckiem i rodzina, Warsaw: Instytut Psychologii Zdrowia, 2009.

Gruszczyński, W. Trauma a zespót stresu pourazowego. In: W przestrzeni stresu i lęku medyczne i społeczne aspekty traumy, ed. J. Jośko-Ochojska. 147-170. Katowice: Śląski Uniwersytet Medyczny, 2016.

Gustak, M., Głuszek-Osuch M. Czynniki warunkujące PTSD u dzieci i młodzieży, In: Konsekwencje psychiczne traumy - uwarunkowania i terapia, ed. J. Strelau, B. Zawadzki, M. Kaczmarek. 154-169. Warsaw: Wydawnictwo Naukowe SCHOLAR, 2009.

Heitzman, J. „Zaburzenia potraumatyczne - możliwości psychoterapeutyczne, przegląd koncepcji”. In: Konsekwencje psychiczne traumy - uwarunkowania i terapia, eds. J. Strelau, B. Zawadzki, M. Kaczmarek. 321-339. Warsaw: Wydawnictwo Naukowe SCHOLAR, 2009.

Jadczak-Szumiło, T., Wrona G. Dziecko pod opieka grupy roboczej. Diagnoza i opracowanie planu pomocy. Poradnik Praktyczny, Kraków: Suprema Lex, 2018.

Kalsched, D., Wewnętrzny świat traumy. Archetypowe obrony jaźni. Poznań: Wydawnictwo Zysk i S-ka, 2015.

Kulig, B., T. Saj, Szkoła wrażliwa na traumę. Warsaw: SOS Wioski Dziecięce, 2019.

Kwarta, P., J. Grzelińska, T. Pietras. „Potraumatyczny rozwój u dzieci i młodzieży - perspektywy badawcze", Postępy Psychiatrii i Neurologii, 3 (2012): 293-297.

Popiel, A., E. Pragłowska. Psychopatologia reakcji na traumatyczne wydarzenia In: Konsekwencje psychiczne traumy - uwarunkowania i terapia, 
eds. J. Strelau, B. Zawadzki, M. Kaczmarek, 38-45. Warsaw: Wydawnictwo Naukowe SCHOLAR, 2009.

Posttraumatic Stress Disorder in the DSM-5: Controversy, Change, and Conceptual Considerations. 2017. https://www.ncbi.nlm.nih.gov/pmc/articles/ PMC5371751/

Skotnicka, B. „Prenatalne, perinatalne i postnatalne czynniki zagrożenia niepełnosprawnością intelektualną: profilaktyka i edukacja”. In: Problemy Edukacji, Rehabilitacji Osób Niepetnosprawnych, 1 (2014), 67-79.

Słaboń-Duda, A. „Wczesna relacja matka - dziecko i jej wpływ na dalszy rozwój emocjonalny dziecka", Psychoterapia, 2 (2011): 11-18.

Spear, L. The Behavioral Neuroscience of Adolescence, New York: W.W. Norton, 2010.

Sczepaniak, A. „Zaburzenia więzi jako efekt wczesnodziecięcego krzywdzenia dziecka", Dziecko krzywdzone. Teoria, badania, praktyka, 3 (2016): 74-90.

Sztompka, P. Trauma wielkiej zmiany, Warsaw: ISP PAN, 2000.

Taylor, Ch. Zaburzenia przywiązania u dzieci i młodzieży. Poradnik dla terapeutów, opiekunów i pedagogów, Sopot: Gdańskie Wydawnictwo Psychologiczne, 2017.

Włodarczyk, J., K. Makaruk, P. Michalski, M. Sajkowska, Ogólnopolska diagnoza skali $i$ uwarunkowań krzywdzenia dzieci 2018. https://diagnozakrzywdzenia.pl/raport.pdf 